\title{
JEAI-MOCAs: A multi-institutional initiative to build marine research capacity in Mozambique
}

AUTHORS:

Issufo Halo ${ }^{1,2}$

Bjorn Backeberg ${ }^{1,2}$

Atanasio Brito ${ }^{3}$

Charine Collins ${ }^{2}$

Obadias Cossa ${ }^{2,4}$

Francisco Gemo ${ }^{5}$

Yonss Jose ${ }^{2}$

Benjamin Loveday ${ }^{2}$

Bernardino Malauene ${ }^{3,6}$

Francis Marsac ${ }^{2,7}$

Clousa Maueua ${ }^{4}$

Olivier Maury ${ }^{2,7}$

Alberto Mavume ${ }^{5}$

Fialho Nehama ${ }^{8}$

Pierrick Penven ${ }^{7,9}$

Stephane Pous ${ }^{2,7}$

Chris Reason ${ }^{2}$

Mike Roberts ${ }^{10}$

Frank Shillington ${ }^{1,2}$

\section{AFFILIATIONS:}

${ }^{1}$ Nansen-Tutu Centre for Marine Environmental Research,

University of Cape Town, Cape

Town, South Africa

${ }^{2}$ Department of Oceanography, University of Cape Town, Cape Town, South Africa

Instituto de Investigação Pesqueira, Maputo, Mozambique ${ }^{4}$ Instituto Nacional de Hidrografía e Navegação, Maputo,

Mozambique

${ }^{5}$ Department of Physics, University Eduardo Mondlane, Maputo, Mozambique

${ }^{6}$ Department of Biological Sciences, University of Cape Town, Cape Town, South Africa

${ }^{7}$ LMI IRD International Centre for Education, Marine and Atmospheric Sciences over Africa, Cape Town, South Africa ${ }^{8}$ Escola Superior de Ciências Marinhas e Costeiras - UEM, Quelimane, Mozambique

'Laboratoire de Physique des Océans, Plouzané, France

${ }^{10}$ Department of Environmental Affairs, Cape Town, South Africa

\section{CORRESPONDENCE TO:} Issufo Halo

EMAIL:

issufo.halo@uct.ac.za

\section{POSTAL ADDRESS:}

Department of Oceanography, University of Cape Town, Rondebosch 7701, South Africa
Understanding the dynamics of the coastal oceans is important for managing coastal ecosystems, and hence for protecting lives and planning sustainable development. Among other countries in the southwest Indian Ocean, Mozambique has a greater number of environmental problems to solve. These problems include the landing of tropical cyclones ${ }^{1}$ along the coast and associated heavy rain and flooding events which cause loss of life, infrastructural damage, coastal erosion, incident droughts, water pollution, overexploitation of marine and coastal resources, and weather and climate change and extremes. ${ }^{2,3}$ Many of these problems can be monitored, so that remedial action can be taken, by conducting sustainable institutional collective research. ${ }^{4}$ Therefore Mozambican institutions should attain adequate capacity of human resources in strategic research areas (e.g. weather and climate extremes, mitigating harmful effects of climate change, and conservation and sustainable management of marine and coastal resources). ${ }^{5}$ It was because of the aforementioned problems that, for the first time, an initiative developed by a Mozambican research group to focus on oceanic and atmospheric dynamics was established.

The newly formed research group - the Mozambican Ocean-Atmosphere scientific research programme (hereafter JEAI-MOCAs) - is primarily composed of nine Mozambican nationals: three senior researchers with PhDs (one based at the Mozambican Institute for Fishery Research (IIP), one at the School of Marine and Coastal Sciences at the University Eduardo Mondlane (UEM), and one at the Department of Physics at UEM, one postdoctoral fellow at the Nansen-Tutu Centre for Marine Environmental Research (NTC) at the University of Cape Town (UCT), three PhD students at UCT, and two MSc graduates of the Department of Oceanography, UCT. The group also has the support of two international PhD students (one British and one South African) in Physical Oceanography based at UCT. JEAI-MOCAs has the supervision of seven international senior scientists (three South African and four French), specialised in different fields of research: physical oceanography, atmospheric sciences and marine ecosystems.

JEAI-MOCAs relies mostly on the experience collected over 15 years of international scientific collaboration between the South African institutions - the Department of Oceanography at UCT and Marine and Coastal Management - and the French Institut de Recherche pour le Développment. Four Mozambican institutions are involved: the Department of Physics at UEM, Escola Superior de Ciências Marinhas e Costeiras at UEM, IIP and the Instituto de Hidrografía e Navegação (INAHINA). The group was formed within the framework of the LMI IRD ICEMASA (International Centre for Education, Marine and Atmospheric Sciences over Africa), in collaboration with the Laboratoire de Physique des Oceans and the NTC.

JEAI-MOCAs is funded by the French Agency, 'Agence Inter-établissements de Recherche pour le Développment' (AIRD). ${ }^{6}$ AIRD's vision is to promote and strengthen new research teams in developing countries, to ensure autonomy, international recognition and development of a collaborative network. The JEAl-MOCAs funding management is structured according to three phases, with each phase corresponding to one year and being entitled to one-third of the total amount funded. JEAI-MOCAs will purchase three Linux-based computing workstations that will be based at three Mozambican institutions: IIP, UEM and INAHINA. These workstations will allow the running of experiments, storage of outputs, and performance of model diagnostics locally. The purchase of computer disks will ensure safe and effective data management, especially during times of poor Internet connectivity (known in developing countries). International missions for the JEAI-MOCAs team have been approved for each year of the programme, and are regarded as a key element for the functioning of the team. These missions include the travel of Mozambican researchers to South Africa and France for collaboration and capacity building, as well as the travel of South African and French researchers to Mozambique for monitoring of the achievements of the programme. Organisation of and participation in summer/winter schools, workshops and symposia are also regarded as important for the JEAI-MOCAs group. The first of such in the series will be organised in parallel with the forthcoming WIOMSA Scientific Symposium which will be held in Maputo, Mozambique from 28 to 30 October 2013.

The JEAI-MOCAs programme was launched in Maputo, Mozambique, at an inaugural 4-day meeting (6-9 May 2013), hosted at Inhaca Marine Biological Station. Twelve delegates attended: nine Mozambican nationals, including the special presence of the Deputy Director of the IIP, and three French senior researchers (Figure 1). Unfortunately, none of the South African researchers were able to attend this meeting. The JEAI-MOCAs meeting was framed across a multidisciplinary collaborative approach, centred within the Mozambique Channel, to include physical oceanography, atmospheric science, climate science and biogeochemistry oriented along three scientific themes: (1) impact of tropical cyclones on the ocean in the Mozambique Channel, (2) effects of the mesoscale eddies of the Mozambique Channel on marine ecosystems, and (3) marine ecosystems along the coasts of Mozambique.

\section{KEYWORDS:}

biogeochemistry; ocean eddies; tropical cyclones; ocean models; tides

\section{HOW TO CITE:}

Halo I, Backeberg B, Brito A, Collins C, Cossa 0, Gemo F, et al. JEAI-MOCAs: A multi-institutional initiative to build marine research capacity in Mozambique. S Afr J Sci. 2013;109(7/8), Art. \#a0023, 2 pages. http://dx.doi.org/10.1590/ sajs.2013/a0023

(c) 2013. The Authors. Published under a Creative Commons Attribution Licence. 


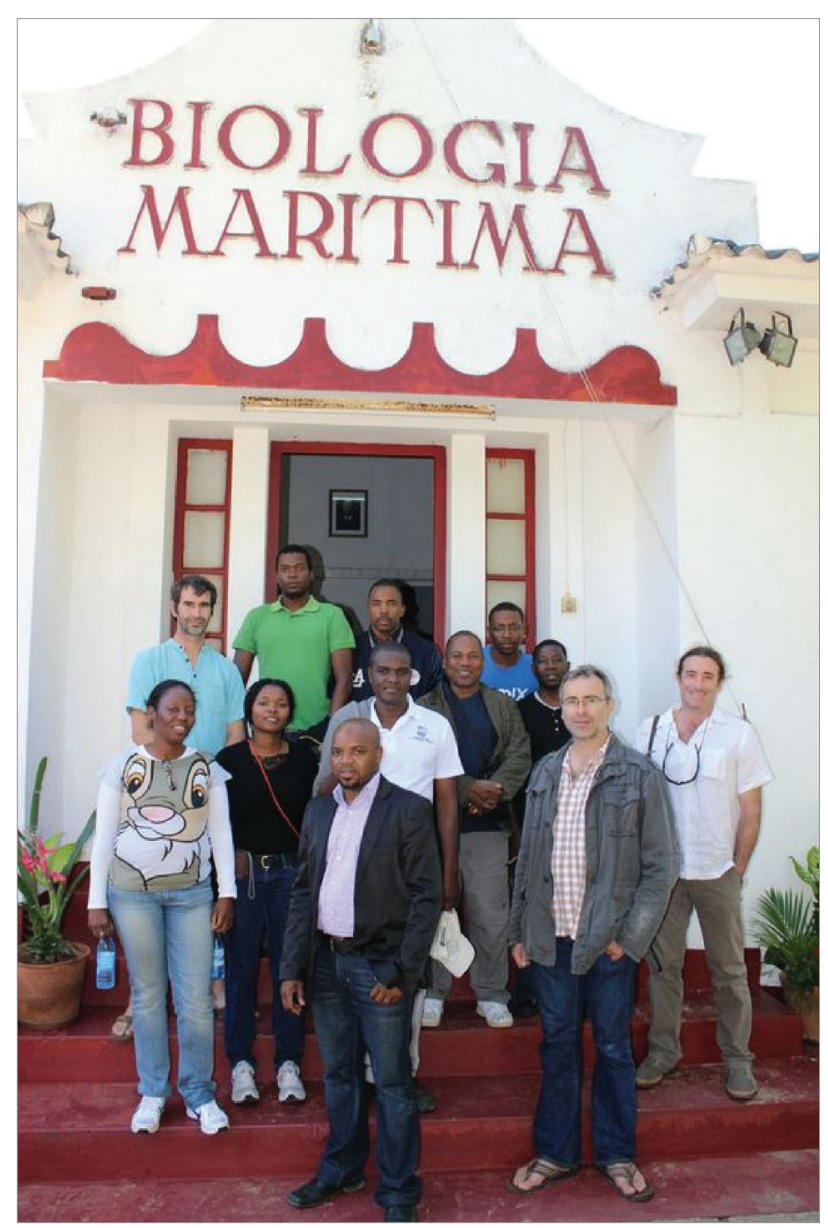

Source: Fialho Nehama

Figure 1: The JEAI-MOCAs group at the launch of the programme at the Inhaca Marine Biological Centre of the University Eduardo Mondlane. From left to right, first row: F. Nehama and P. Penven; second row: C. Chevane, Y. Jose, A. Brito, A. Mavume, I. Halo and O. Maury; third row: S. Pous, B. Malauene, O. Cossa and F. Francisco.

The JEAI-MOCAs inaugural meeting highlighted a series of scientific presentations in which the present state of knowledge and knowledge gaps covering multidisciplinary topics within the three scientific themes were presented. The scientific approach in each theme and the required research equipment were proposed. Because of a scarcity of in-situ data in the Mozambique Channel, the JEAI-MOCAs group relies mostly on a set of several numerical models. These models have been tested and they reproduced reasonably well the oceanic dynamics in the southwest Indian Ocean. ${ }^{7}$ The Regional Ocean Modelling System model $\left(\mathrm{ROMS}^{8}\right)$ is used for hydrodynamics research, the biogeochemical model PISCES ${ }^{9}$ for studies on marine biological productivity, and the mid-trophic Apex Predator ECOSystem Model $\left(\mathrm{APECOSM}^{10}\right)$ for zooplankton and fish dynamics research.

The first scientific theme covered a general description of the tropical cyclones in the southwest Indian Ocean, with a focus on their impact in the Mozambique Channel. It also included the physical and biochemical oceanic response to tropical cyclones, and the extreme sea surface elevation (storm surge) response to tropical cyclones.

The second theme addressed the need for in-situ observations of the Mozambique Channel eddies, especially in the southern part of the channel. The recent developments and analysis of the ocean models, ROMS-AGRIF configurations, simulating the Mozambique Channel eddies and their propagation along the Mozambican coastline were also reported on. Furthermore, a description of the coupling of the ROMSAGRIF configuration to the PISCES and APECOSM models was given. Other topics addressed were the analysis of the different solutions and sensitivity tests of the Mozambique Channel eddies in a global higherresolution model (NEMO11). A topic addressing the cyclogeostrophic balance in the Mozambique Channel was also brought to the attention of the scientific members.

The third theme addressed the development of a high-resolution model for shrimp larval transport and dispersal on the Sofala Bank, in which the tides and the river plumes can be resolved. It also described the coupling approach of ROMS with an individual based model using the Ichthyop model. ${ }^{12}$ Other topics included the test of the effects of the tides, the river plumes and the Mozambique Channel eddies on shelf circulation and stratification on the Sofala Bank, modelling of the internal waves in Delagoa Bigh, and studies on sea level changes in the Western Indian Ocean and South Atlantic Ocean.

The ultimate goal of JEAI-MOCAs is to create and strengthen the research capacity of a well-motivated group of oceanographers and atmospheric scientists in Mozambique. The programme is expected to improve the current understanding of the oceanic and atmospheric processes occurring in the Mozambique Channel. Such an understanding may ensure a better management of the marine resources, which can contribute to better living conditions in Mozambique.

\section{References}

1. Mavume AF, Rydberg L, Rouault M, Lutjeharms JRE. Climatology of tropical cyclones in the South-West Indian Ocean; landfall in Mozambique and Madagascar. Western Indian Ocean J Mar Sci. 2009;8:15-36.

2. Brundrit $G$, Mavume AF. Future impacts of climate change on cyclone, storm surge and sea level rise activity. In: Asante K, Brito R, Brundrit G, Epstein P, Fernandes A, Marques MR, et al., editors. INGC study on the impact of climate change on natural disaster risk and adaptation in Mozambique. Technical report. Maputo: INGC; 2009. p. 33-66.

3. Meyer AAM. Responding to climate change in Mozambique: Theme 8: Oceanic climate change under continued global warming. Technical report. Stellenbosch: CSIR; 2012.

4. Van Logchem B, Queface AJ. Responding to climate change in Mozambique: Synthesis report. Technical report. Maputo: INGC; 2012.

5. Monteiro 0, Mavume AF. Responding to climate change in Mozambique: Theme 9: Proposed national strategy on disaster risk reduction and climate change adaptation. Technical report. Maputo: INGC; 2012.

6. Direction des programmes de recherche et de la formation au Sud Service Renforcement des capacités/JEAl. Call for proposals. Technical report. Marseille: IRD; 2012. Available from: http://www.ird.fr/-ird-dans-le-monde

7. Halo I, Backeberg B, Penven P, Ansorge I, Reason C, Ullgren JE. Eddy properties in the Mozambique Channel: A comparison between observations and two numerical ocean circulation models. Deep Sea Res II. In press 2012.

8. Shchepetkin AF, McWilliams JC. The regional oceanic modeling system (ROMS): A split-explicit, free-surface, topography-following-coordinate oceanic model. Ocean Modelling. 2005;9:347-404.

9. Aumont O, Maier-Reimer E, Blain S, Monfrey P. An ecosystem model of the global ocean including $\mathrm{Fe}, \mathrm{Si}, \mathrm{P}$ colimitations. Glob Biogeoch cycles. 2003;2:1-15.

10. Maury 0. An overview of APECOSM, a spatialized mass balanced Apex Predators ECOSystem Model to study physiologically structured tuna population dynamics in their ecosystem. Prog Oceanog. 2010;84:113-117.

11. Madec G. NEMO reference manual, ocean dynamics component: NEMO-OPA note du pole de modelisation. Technical report. Paris: Institut Pierre-Simon Laplace; 2006.

12. Lett C, Verley P, Mullon C, Parada C, Brochier T, Penven P, et al. Ichthyop: A Lagrangian tool for modelling ichthyoplankton dynamics. Env Model Soft. 2008;23:1210-1214. http://dx.doi.org/10.1016/j.envsoft.2008.02.005 